\title{
GLOBAL GEOPARKS NETWORK AND THE NEW UNESCO GLOBAL GEOPARKS PROGRAMME
}

\author{
Zouros N. ${ }^{1}$ \\ ${ }^{1}$ University of the Aegean, Department of Geography, 81100 Mytilene Greece,nzour@aegean.gr
}

\begin{abstract}
The Geopark concept was introduced at late 90's aiming to protect and promote Earth heritage sites through the sustainable local development of territories containing abiotic nature of significant value.

The Global Geoparks Network (GGN) established in 2004 operates as an international platform of cooperation among Geoparks around the world The GGN includes 120 Geoparks in 33 countries working to protect Geological heritage and promote local sustainable development.

The 38th UNESCO General Conference (November 2015) ratified the statutes of the new International Geoscience and Geoparks Programme and the UNESCO Global Geoparks Operational Guidelines, introducing the brand UNESCO Global Geopark as a label of excellence for areas that meet the criteria set by the above mentioned guidelines.

In doing so, it has legally endorsed the new UNESCO label of "UNESCO Global Geopark" and the endorsement of all the existing 120 Global Geoparks to become UNESCO Global Geoparks with immediate effect.

The UNESCO Global Geopark branding could strongly contribute to raising Earth Heritage sites visibility in the world and in high-quality public outreach on sustainable development linked to issues on geodiversity, the environment, geohazards, climate change and the sustainable use of natural resources.
\end{abstract}

Keywords: Geological Heritage, management, geotourism, sustainable development.

\section{Introduction}

The Geopark concept was introduced at late 90's following the declaration of the International Symposium on the Conservation of the Geological Heritage organized under the auspices of UNESCO in Digne France in 1991, aiming to protect and promote Earth heritage sites through the sustainable local development of territories containing abiotic nature of significant value.

The Geoparks concept adds a new dimension to the 1972 World Heritage Convention by highlighting the potential for interaction between socio-economic and cultural development and the conservation of the natural environment.

The European Geoparks Network (EGN) was the first network of Geoparks, established in 2000 by four European territories to address the strong need for effective management of important geosites and sustainable development of rural areas through the development of geotourism in Europe.

The Global Geoparks Network (GGN) was established in 2004, under the umbrella of UNESCO and operates as an international network, providing a platform of cooperation among Geoparks, bringing together government agencies, non-governmental organizations, scientists and experts from all countries around the world in a unique worldwide partnership. The GGN includes 120 
Geoparks in 33 countries working to protect Geological heritage and promote local sustainable development.

The General Assembly of the GGN voted unanimously in September 2014 to establish themselves as a not-for-profit legal association which is now created and based in France. The GGN also agreed that the new association will donate a sum totaling no less than 1000 USD per Global Geopark to UNESCO annually to assist the Organization in capacity building activities for Global Geoparks.

\section{The Global Geoparks Network}

Thus the GGN, since September 2014, is a non-profit association subject to French legislation (the 1901 law on associations) and a non-governmental organization maintaining formal relations with the United Nations Educational, Scientific and Cultural Organization (UNESCO).

According to its statutes the GGN is the international organisation of the Global Geoparks and Global Geopark professionals which is committed to the conservation, management and communication to society of the Earth heritage as an integral part of the world's natural and cultural heritage, tangible and intangible.

Global Geoparks are tools to conserve and enhance the value of areas of geological significance in Earth history, including landscapes and geological formations, which are key witnesses to the evolution of our planet and determinants for our future and to promote sustainable development for example through geo-tourism and education.

\subsection{Categories of Membership}

There are different categories of membership within GGN.

1. Institutional Members - Global Geoparks. Participation in GGN is obligatory for all territories nominated as Global Geoparks.

2. Individual Members - Global Geopark Professionals - Persons who have combined or proved professional experience in Global Geopark management.

3. Honorary Members.

4. Cooperating Members.

\subsection{Structure of the Global Geoparks Network}

The GGN structure according to its statutes composed as follows:

1.General Assembly

2.Executive Board

3.Advisory Committee

4.National Geopark Committees

5.International Committees / Task Forces / Working groups

6.International Conference on Geoparks

7.Regional Geopark Networks

8.Affiliated Organisations

9.Operational Secretariat

The GGN establishes ethical standards which must be adopted and respected by Global Geoparks and Global Geopark professionals. 
The GGN organises co-operation and mutual assistance between Global Geoparks and between Global Geopark professionals.

The GGN initiates and co-ordinates Regional Geoparks Networks which will foster international cooperation and promotion of sustainable development.

The GGN represents, advances, and disseminates knowledge in Geodiversity management and other disciplines related to studies in Geo-conservation, Geo-tourism, Geo-education and/or the management and activities of Global Geoparks.

\subsection{Regional Networks}

Recognising the very strong role networking has played in the success of the Global Geoparks movement and recognizing the valuable role it plays in facilitating the sharing of experience, formation of joint initiatives and projects and the highly significant role it plays in capacity-building, the GGN will encourage the strengthening of Regional Geopark Networks.

Regional Geopark Networks include GGN members at a regional or continental level.

Regional Geopark Networks serve for the coordination of GGN activities at a regional or continental level and as fora for the exchange of information and co-operation between Global Geoparks and Global Geopark professionals in the region.

The activities of Regional Geopark Networks include the organisation of Regional Geopark Conferences, workshops and seminars, capacity building activities, common projects, promotional activities and common publications.

Each Geopark Network forms a Coordination Commission which is the governing body of the Regional Network and elects two Coordinators and an Advisory Committee according to the Regional Geopark Network Rules of operation.

\section{Global Geoparks Network and UNESCO}

Since the creation of the GGN in 2004, Global Geoparks have gained momentum and their achievements have attracted the attention of an increasing number of Member States. Global Geopark activities have been part of the UNESCO work plan since 2001 and, since 2004, UNESCO has offered ad-hoc support to Global Geoparks upon requests from individual Member States. However, the role of UNESCO in supporting the worldwide activities is limited and 'Geoparks' are not a programme of UNESCO per se.

Following the decisions of the 36th and 37th sessions of the UNESCO General Conference the ExB formed a Working Group on Geoparks held since 2013 with Member States, National Commissions, the Global Geoparks Network (GGN), and the International Union of Geological Sciences (IUGS). The outcome of seven meetings of the Working Group on Geoparks proposed the parameters of possible UNESCO Global Geopark activities within an International Geoscience and Geoparks Programme (IGGP).

On November 17th the 38th UNESCO General Conference ratified the statutes of the new International Geoscience and Geoparks Programme and the UNESCO Global Geoparks Operational Guidelines, introducing the brand UNESCO Global Geopark as a label of excellence for areas that meet the criteria set by the above mentioned guidelines.

In doing so, it has legally endorsed the new UNESCO label of "UNESCO Global Geopark" and the endorsement of all the existing 120 Global Geoparks to become UNESCO Global Geoparks with immediate effect.

The UNESCO Global Geopark branding could strongly contribute to raising UNESCO's visibility in the world and allow UNESCO to take the lead in high-quality public outreach on sustainable development linked to issues on geodiversity, the environment, geohazards, climate change and the 
sustainable use of natural resources. Moreover, it has been identified that this branding could also be of clear advantage for the development of Global Geoparks in those regions where none currently exist and for the Secretariat's fundraising scheme which will be the main source to assist countries in the development of Global Geoparks.

\section{Criteria for UNESCO GLOBAL GEOPARKS}

i. UNESCO Global Geoparks must be single, unified geographical areas where sites and landscapes of international geological significance are managed with a holistic concept of protection, education and sustainable development. A UNESCO Global Geopark must have a clearly defined border, be of adequate size to fulfil its functions and with geological heritage of international significance as independently verified by scientific professionals.

ii. UNESCO Global Geoparks should use that heritage, in connection with all other aspects of that area's natural and cultural heritage, to promote awareness of key issues facing society in the context of the dynamic planet we all live on, in particular to increase knowledge and understanding of: geohazards; climate change; the need for the sustainable use of Earth's natural resources; and the empowerment of indigenous peoples.

iii. UNESCO Global Geoparks should be areas with a management body having legal personality recognised under national legislation. The management bodies should be appropriately equipped to adequately address the area of the UNESCO Global Geopark in its entirety.

iv. In the case where an applying area overlaps with another UNESCO designated site, such as World Heritage Site or Biosphere Reserve, the request must be clearly justified and evidence must provided for how UNESCO Global Geopark status will add value by being both independently branded and in synergy with the other designations.

v. UNESCO Global Geoparks should actively involve local communities and indigenous peoples as key stakeholders in the Geopark. In partnership with local communities, a comanagement plan needs to be drafted and implemented that provides for the social and economic needs of local populations, protects the landscape in which they live and conserves their cultural identity. It is recommended that all relevant local and regional actors and authorities be represented in the management of a UNESCO Global Geopark. Local and indigenous knowledge, practice and management systems, should be included, alongside science, in the planning and management of the area.

vi. UNESCO Global Geoparks are encouraged to share their experience and advice and to undertake joint projects within the GGN. Membership of GGN is obligatory.

vii. A UNESCO Global Geopark must respect local and national laws relating to the protection of geological heritage. The defining geological heritage sites within a UNESCO Global Geopark must be legally protected in advance of any application. At the same time, a UNESCO Global Geopark should be used as leverage for promoting the protection of geological heritage locally and nationally. The management body must not participate directly in the sale of geological objects such as fossils, minerals, polished rocks and ornamental rocks of the type normally found in so-called rock-shops within the UNESCO Global Geopark (regardless of their origin) and should actively discourage unsustainable trade in geological materials as a whole. Where clearly justified as a responsible activity and as part of delivering the most effective and sustainable means of site management, it may permit sustainable collecting of geological materials for scientific and educational purposes from naturally renewable sites within the UNESCO Global Geopark. Trade of geological materials based on such a system may be tolerated in exceptional circumstances, provided it is clearly and publicly explained, justified and monitored as the best option for the Geopark in relation to local circumstances. Such circumstances will be subject to approval by the UNESCO Global Geoparks Council on a case by case basis. 


\section{Structure of the UNESCO GLOBAL GEOPARKS}

\subsection{UNESCO Global Geoparks Council}

The Council is the decision-

making body for new UNESCO Global Geopark applications and revalidations and it is responsibl e for advising the Director-

General on the strategy planning and implementation of the Global Geoparks activity of the IGGP. The Council is composed of twelve ordinary members, with the right to vote, who are individuals appointed by the Director-General of UNESCO on recommendation of GGN and Member States. I $\mathrm{n}$ addition, the Director-General of UNESCO, the President of GGN, the Secretary-General of IU GS, the Director-General of IUCN or their representatives shall be ex officio members of the Coun cil without the right to vote.

Ordinary Members appointed to the Council shall be high-profile experts chosen for their proven e xperience, scientific or professional qualification in relevant fields, taking into account an equitabl e geographical distribution and gender equality. Ordinary Members will serve in their personal capacity, not as representatives of their respective states or any other affiliated entities. Council members will have to agree in writing that they will abstain in cases of conflict of interest regarding new UNESCO Global Geopark applications or those requiring revalidation.

\subsection{UNESCO Global Geoparks Bureau}

The Bureau will consist of five members: the Chairperson, the Vice-Chairperson and the Rapporte ur of the Council of the UNESCO Global Geoparks. The Director-General of UNESCO and the Pr esident of the Global Geoparks Network (GGN) or their representatives shall be ex officio member $\mathrm{s}$ of the Bureau without the right to vote.

Its main duty, will be to prepare with the secretariat the necessary documentation for the Executive Board of UNESCO to provide a final endorsement of new UNESCO Global Geopark nominations based on decisions of the Council. The UNESCO Global Geoparks Bureau will hold joint coordination meetings with the Bureau of the International Geoscience Cooperation Projects (IGCP).

\subsection{UNESCO Global Geoparks Evaluation Team}

UNESCO Global Geoparks will be evaluated - both during the initial application and during revalidation - by an independent team composed of desk-top advisors and field evaluators.

The UNESO Secretariat in conjunction with the GGN will establish and maintain a roster of field evaluators who will undertake field evaluations of new applications for aspiring UNESCO Global Geoparks. These field evaluators will have combined and proven professional experience relevant for geopark development (geological heritage, conservation, sustainable development, tourism development and promotion, and environmental issues). These field evaluators will also conduct revalidation missions.

Evaluators for UNESCO Global Geoparks must follow strict guidelines provided by the Council for new application and revalidation missions. These evaluators will serve in their personal capacity, not as representatives of their respective states or any other affiliated entities. GGN will be required to ensure that field evaluators have no conflict of interest regarding new UNESCO Global Geopark applications or those requiring revalidation. Evaluators will not seek or accept instructions from governments or other authorities and will not conduct missions in their own country. If any National Geopark Committee seeks to observe an evaluation or revalidation mission, it will be fully up to the field evaluators which observations and information provided they will include into their final reports. They are expected to submit their reports to UNESCO in a timely manner. Field evaluators will not have the status of "experts on mission" pursuant to the Convention on the Privileges and Immunities of the United Nations of 1946. 


\section{National Geopark Committees}

Member States should play an active role in the development of their UNESCO Global Geoparks. As such, and only if the Member State wishes to do so, the creation of a National Geopark Committee is recommended. These 'National Committees' could be named differently, for example, National Forum, National Task Force or Task Group. These committees may be created by the competent entity in charge of Geoparks in that Member State. The committees must be recognised by that Member State's National Commission for UNESCO or the relevant Government body in charge of relations with UNESCO.

Its work at national level may consist of:

- Coordinating the national contribution to UNESCO Global Geoparks within the IGGP;

- Identifying the geological heritage and raising public awareness of its importance;

- Promoting the development of new UNESCO Global Geoparks, assessing and endorsing applications and revalidations;

- Observing any evaluation or revalidation mission in that Member State should they wish to;

- Presenting to that Member State's National Commission for UNESCO or the relevant Government body in charge of relations with UNESCO all UNESCO Global Geopark applications, which will then be forwarded to UNESCO.

- Ensuring the proper withdrawal of the area as a UNESCO Global Geopark within the IGGP, should the area so wishes or should they fail the revalidation process;

- Promoting international cooperation between UNESCO Global Geoparks;

- Providing information at the national level about the global and regional networks of UNESCO Global Geoparks;

- Initiating and supporting strategies and actions for sustainable development in and among UNESCO Global Geoparks;

The UNESCO Secretariat will liaise closely with National Geopark Committees and Member State's National Commission for UNESCO or the relevant Government body in charge of relations with UNESCO at all stages during the evaluation and revalidation processes of aspiring and existing UNESCO Global Geoparks.

All applications and revalidations must be accompanied by a letter of support from the National Commission for UNESCO or the relevant government body in change of relations with UNESCO.

\section{Application Procedure}

An aspiring Global Geopark can apply to UNESCO for designation through a rigorous procedure, the precise details and deadlines of which are available on the UNESCO website.

Ahead of any formal application, any aspiring UNESCO Global Geopark should submit an expression of interest via the official channel as defined by the National Commission for UNESCO or the government body in charge of relations with UNESCO, involving, if applicable, the National Geoparks Committee.

A comprehensive and carefully formatted application dossier (including supporting material to demonstrate that the area has already been functioning as a de facto Global Geopark for at least one year) should be submitted through the official channel as defined by the National Commission for UNESCO or the Government body in charge of relations with UNESCO to the UNESCO Secretariat involving, if applicable, the National Geoparks Committee. This should be accompanied by an explicit endorsement of any relevant local and regional authorities and a letter of support from the National Commission for UNESCO or the Government body in charge of relations with UNESCO. 
The UNESCO Secretariat shall involve the main national contact point in all communication with the aspiring Global Geopark, including the findings of the field evaluation mission, the outcome of the decisions of the Council, and the endorsement by the UNESCO Executive Board.

In order to ensure a balanced geographical representation of UNESCO Global Geoparks, the number of "active" applications is limited to two per Member State. An application is considered "active" upon receipt of the dossier by the UNESCO Secretariat and ceases to be active once a final decision is made regarding its designation as a UNESCO Global Geopark, or if the application is suspended.

Only applications from UNESCO Member States will be considered for designation as a UNESCO Global Geopark.

\section{Global Geoparks Activities}

The GGN mission is to influence, encourage and assist local societies all over the world to conserve the integrity and diversity of abiotic and biotic nature, to ensure that any use of natural resources is equitable and sustainable and to support economic and cultural development of local communities through the valorisation of their unique heritage and identity.

A broad range of activities combines the main components for the operation of each Geopark, including scientific research, inventory of geological sites, protection and conservation of geological heritage, operation of open air parks, thematic museums and interpretation centers, interpretation and promotion of geological sites, organization of scientific and cultural events.

Geoparks also promote themselves as ideal destinations for geotourism and educational activities. Main target group for educational activities in Geoparks are schoolchildren and University students, while geo-tourism in a form of tourism that sustains, or even enhances, the identity of a place, such as its environment, culture, heritage, and the well-being of its residents.

Through Geoparks operation important geological sites gain worldwide recognition and benefit through the exchange of knowledge, expertise, experience and staff among Geoparks.

During the last years Geoparks following the provisions of their management plan implemented a range of activities aimed at the further improvement of its infrastructure, services, activities and promotion.

The results of the implementation of the management plan have been a significant increase in the number of visitors, the enrichment of their offer and services to visitors and improvement of their operation.

\section{Global Geoparks and Local Development}

An important component of the Geopark management plan is the support of the local economy. Geoparks create links with local tourist enterprises, restaurants and small hotels in order to provide the necessary infrastructure to meet the needs of the increasing number of park visitors. The majority of visits to the Geopark occur during the summer period (July - September), but the aim is to extend the visiting period to the spring and autumn seasons.

Geoparks can present impressive results in this field. In some cases the number of "Bed and Breakfast" accommodations has doubled over the last few years in order to meet the increasing demand. More importantly, visitors have increased the duration of their visit to the Geopark area. As a result many new enterprises are connected with the activities of the Geopark.

The Geopark also supports the making of local handicrafts such as the production of fossil casts and souvenirs by local enterprises. These items are on sale in the Geopark shop along with a variety of other locally made products and the Geopark promotes these products to its visitors.

Geoparks also collaborates closely with women's agrotouristic cooperatives and local organic food producers to offer their visitors the opportunity to taste and buy local food products (pasta, organic vegetables, wine, liquors, traditional sweets and marmalades etc.). The catering for all Geopark 
events (conferences, meetings etc.) is supplied using the local traditional food. The Geoparks organize Agro-touristic festivals, which promotes quality local products, food and drinks. The event brings local producers and potential customers together. In this way Geopark visitors experience not only the rich natural heritage of the area and sites of high ecological and aesthetic value, but also the culture, tradition, and local production of the region. The Women's agrotouristic cooperative found that this festival provided them with an excellent opportunity to promote their products and their success lead to the creation of similar cooperatives in other villages

Geoparks contribute significantly to territorial development by directly and indirectly creating new jobs. But what is even more important for the employment in the area is the number of other job opportunities which are created in tourist enterprises, small hotels, guest houses, restaurants and other activities connected with the increase of tourist flow in the Geopark area.

Several other local artisans, such as makers of handicrafts and ceramic fossil casts, carpenters, and blacksmiths, are permanent collaborators with the Geopark.

\section{Global Geopark Networking}

Geoparks continuously seek for international cooperation with other partners on common interests. Such cooperation facilitates the development and transfer of new methodologies and approaches for the management of Natural parks and Geoparks through linking biotic and abiotic factors, landscape and cultural heritage in nature conservation strategies and action plans, sharing of know-how and new approaches to improve landscape interpretation, sensitisation and understanding of natural heritage issues, and the development of educational and touristic activities.

Cooperation results are positive and help Geoparks reach an effective management strategy and a high level of services and infrastructure.

The results of its operation prove the potential of the Geoparks across the globe to be powerful new tools for holistic nature conservation and sustainable rural development through geotourism.

\section{References}

European Geoparks Magazine, Issues No 1-13. Published by the European Geoparks Network, www.europeangeopraks.org.

Global Geoparks Network, 2014. Statutes of the Global Geoparks Network, www.globalgeoparksnetwork.org.

Mc Keever, P. and Zouros, N., 2005. Geoparks: Celebrating earth heritage, sustaining local communities, Episodes, 28(4), 274-278.

Mc Keever, P., Zouros, N. and Patzak, M., 2009. Global Network of National Geoparks, World Heritage, 52, 54-59.

UNESCO, 2015. UNESCO Global Geoparks Operational Guidelines, www.unesco.org.

Zouros, N., 2004. The European Geoparks Network. Geological heritage protection and local development, Episodes, 27(3), 165-171.

Zouros, N. and Mc Keever, P., 2008. European Geoparks - Tools for earth heritage protection and sustainable local development. In: European Geoparks, Zouros, N., ed., Published by the European Geoparks Network, ISBN 9789607646910, 15-30.

Zouros, N., 2012. Measuring progress in European Geoparks: a contribution for a smart, sustainabl e and inclusive growth of Europe, $11^{\text {th }}$ European Geoparks Conference, Arouca Geopark, P ortugal, September 2012, Abstract volume.

Zouros, N., 2013. European Geoparks: new challenges and innovative tools towards Earth heritage management and sustainable local development, 12th European Geoparks Conference, National Park of Cilento, Vallo di Diano and Alburni Geopark, 09/2013. 
